\title{
GROWTH SENSITIVITY TO DROUGHT OF CO-OCCURRING PINUS SPP. ALONG AN ELEVATION GRADIENT IN NORTHERN MEXICO
}

\author{
Isaac N. Bickford ${ }^{1}$, Peter Z. Fulé2,3, and Thomas E. Kolb²
}

\begin{abstract}
Climate change is predicted to increase the frequency of severe drought, yet little information exists on the impacts of drought on dominant trees of Mexican pine forests, which are among the most biologically diverse forests in the world. We conducted the first comparison of growth sensitivity to drought of two co-occurring Pinus species in Mexico to understand whether growth of dominant pines of the Sierra Madre Occidental in northern Mexico is sensitive to drought and temperature variation and to understand how sensitivity differs between tree species and elevations. We sampled and analyzed tree-ring data across a 400-m elevation gradient for the years 1945-2004 for co-occurring Pinus engelmannii and Pinus lumholtzii at Basaseachi National Park, Chihuahua, Mexico. We hypothesized that growth sensitivity to drought would be highest at low elevations, annual basal area increment (BAI) would be lowest at low elevations, and winter precipitation would covary positively with BAI at all elevations. Growth sensitivity to drought, as measured by a wet-dry ring-width index ratio (W:D), was significantly higher for both species at low elevations (W:D range 2.2-2.8) than at intermediate and high elevations (W:D range 1.5-1.9). Pinus engelmannii had significantly higher W:D (2.2) than P. lumholtzii (1.8). Annual BAI did not differ between elevations or species. Annual ring-width index was positively and significantly associated with winter (December-April) precipitation. This association was stronger at low elevations than at high elevations. Other seasons of precipitation and other climatic variables were not significantly associated with annual growth. Our results suggest that the increasing frequency and severity of drought predicted for this region in the coming decades will reduce growth of $P$. engelmannii and P. lumholtzii, with greater impacts on low-elevation populations and on P. engelmannii.
\end{abstract}

RESUMEN.-Se ha predicho que el cambio climático aumentará la frecuencia de las sequías severas, pero existe poca información sobre el impacto de la sequía en los árboles dominantes de los bosques de pino mexicanos, que son de los bosques con más diversidad biológica en todo el mundo. Llevamos a cabo la primera comparación de la sensibilidad a la sequía de dos especies simpátricas de Pinus en México para saber si el crecimiento de los pinos dominantes de la Sierra Madre Occidental en el norte de México es sensible a la sequía y a la variación en la temperatura y cómo la sensibilidad difiere entre especies y a diversas altitudes. Muestreamos y analizamos datos de anillos de Pinus engelmannii y Pinus lumholtzii simpátricos en el Parque Nacional Basaseachi, en Chihuahua, México, a lo largo de un gradiente altitudinal de $400 \mathrm{~m}$ y para los años 1945-2004. Planteamos las hipótesis de que la sensibilidad a la sequía sería mayor a baja altitud, que el incremento del área basal (IAB) anual sería menor a baja altitud y que la precipitación invernal tendría una correlación positiva con el IAB a cualquier altitud. La sensibilidad a la sequía, medida por el índice de la proporción del grosor de los anillos entre temporadas húmedas y secas (H:S), fue significantemente mayor para ambas especies en altitudes bajas (H:S entre 2.2 y 2.8) en comparación con altitudes elevadas o intermedias (H:S entre 1.5 y 1.9). Pinus engelmannii tuvo una proporción H:S significantemente más alta (2.2) que P. lumholtzii (1.8). El IAB anual no difirió entre altitudes o especies. El índice del grosor anual de los anillos tuvo una asociación positiva y significantiva con la precipitación invernal (de diciembre a abril). Esta asociación fue más fuerte en las altitudes bajas que en las elevadas. El crecimiento anual no tuvo una asociación significativa con otras temporadas de precipitación ni con otras variables climáticas. Nuestros resultados indican que el aumento en la frecuencia y severidad de sequías que se predice para esta región en décadas venideras disminuirá el crecimiento de P. engelmannii y P. lumholtzii, surtiendo mayores efectos sobre $P$. engelmannii y sobre las poblaciones de baja altitud.

Recent projections of climate change forecast warmer temperatures and lower precipitation in southwestern North America (Seager et al. 2007, 2009). Severe drought has occurred in northern Mexico since 1994 (Stahle et al. 2009), and future drought is predicted to be more severe than past drought (Seager et al. 2007, 2009). Climate-warming and increased drought have the potential to influence plant growth and range distributions for many species (Fekedulegn et al. 2003, Adams and Kolb 2005, Breshears et al. 2008, Kelly and Goulden 2008), because water is currently the most limiting factor to tree growth in most of the southwestern United States and northern Mexico (Fritts 1976, Swetnam and Betancourt 1998, Seager et al. 2009). Ranges of some tree species are already changing due to chronic water stress that results in higher mortality of trees at low elevations (Kelly and Goulden 2008, McDowell et al. 2010). 
Elevation gradients can be used to study species' responses to climate warming because lower elevations tend to be warmer than higher elevations at similar latitudes (Fritts 1974, Van de Water et al. 2002, McDowell et al. 2010). Fritts (1976) discussed Douglas' 1914 observations that Pinus ponderosa trees at lower elevations exhibited greater variability in ring width than trees at high elevations. Adams and Kolb (2005) used a 1500-m elevation gradient and dendrochronological methods to compare the growth response to regional drought and temperature among 8 tree species in northern Arizona. They found that sensitivity to drought was greater for trees that occurred at low elevations than for trees at high elevations and that sensitivity to drought was greatest for low-elevation populations within single tree species. Kelly and Goulden (2008) surveyed plant cover along a 2314-m elevation gradient in southern California and found that average elevation increased by about $65 \mathrm{~m}$ for the dominant plant species over a 30-year period (1977-2007). They speculated that the shift in species' ranges was predominantly caused by changes in precipitation and temperature rather than by other factors such as air pollution. McDowell et al. (2010) reported that a low-elevation population of $P$. ponderosa in northern New Mexico had greater growth sensitivity to drought and lower annual growth than populations at high elevations. Pinus ponderosa trees that recently died at low elevations had little radial growth in the years preceding death and exhibited the highest growth sensitivity to drought. Each of these studies showed greater impacts of regional drought on plants at low elevations compared with plants at high elevations.

Winter precipitation prior to a given growing season has been strongly correlated with the width of tree rings for that growing season, because trees are deep-rooted organisms that depend on moisture in deep soil layers (Fritts 1976). Winter precipitation is better able to recharge these deep-soil moisture reserves than precipitation in other seasons. Fritts et al. (1965) examined relationships between climate and ring width in Douglas-fir (Pseudotsuga menziesii), pinyon pine (Pinus edulis), ponderosa pine (P. ponderosa) and Utah juniper (Juniperus osteosperma). For all 4 species, they found that winter precipitation prior to the growing season was strongly associated with annual ring-width growth. Fritts (1965) found that summer precipitation was poorly correlated with ring widths in western North America compared to correlations for other seasonal precipitation values. Adams and Kolb (2005) used tree-ring measurements of 8 tree species in northern Arizona to examine relationships between many climatic variables and tree growth and found that in tree populations below $3300 \mathrm{~m}$ above sea level (asl), annual variation in precipitation was more limiting to tree growth than variation in temperature. They also found that winter precipitation prior to a growing season was generally more closely correlated with tree growth than the precipitation of any other season. Salzer and Kipfmueller (2005) used tree-ring series to reconstruct precipitation and temperature for the southern Colorado Plateau, Arizona. They found that annual tree growth was most strongly correlated with precipitation from the previous October-July of the growing season. VillanuevaDiaz et al. (2007) used tree-ring series to reconstruct winter and spring precipitation in northeastern Mexico. They found that tree earlywood thickness depended most on precipitation from January through June of the growing season.

Mexico is one of the most biologically diverse countries in the world. There are 47 pine species recognized in Mexico, which constitute $43 \%$ of the 110 pine species (Farjon and Styles 1997). Approximately 32.8 million ha of the country are covered by pine, mixed conifer/ hardwood, and hardwood forests (SEMARNAT 2002). Despite the diversity and importance of pine species in Mexico, relatively little is known about the impacts of drought on Mexican pines. Although an exhaustive literature review of this topic is beyond the scope of this study, we briefly discuss 4 studies here. Diaz et al. (2001) used tree rings of Pinus lagunae to reconstruct September-July precipitation from 1862 to 1996 and compared that reconstruction to patterns of El Niño-Southern Oscillation (ENSO). They found that the study area experienced a sustained drought from 1939 to 1958, and that El Niño events were associated with above-average precipitation, while La Niña events were associated with below-average precipitation. Biondi (2001) developed a treering chronology for Pinus hartwegii at treeline in Nevado de Colima. He found that summer monsoon precipitation was the strongest dendroclimatic signal for this species and study area. Asbjornsen et al. (2004) studied the effects 
of edge environments and drought on 5 native tree and shrub species along a fragmentation gradient in Oaxaca, Mexico. They found that oak species experienced high water stress as a result of low predawn water potential, which prevented their successful establishment in open areas. In contrast, shrub and pine species had greater growth and survival success as a result of their fast leaf turnover in drought conditions and ability to maintain higher predawn water potentials. Figueroa-Rangel et al. (2008) discussed the role of drought cycles in the late Holocene expansion of pine-dominated forests of west central Mexico. They found that pine-dominated forests are the native vegetation type in the study area, not secondary succession derived from anthropogenic causes. They also found that drought and naturally induced burning appear to be the dominant factors that drive expansion of pine-dominated forests. However, few or no studies have addressed drought impacts on pine growth in Chihuahua, a major forest region of Mexico, where pines make up $82 \%$ of the total annual logged timber volume (Ruelas Monjardin and Dávalos Soteno 1999).

We studied growth responses of co-occurring $P$. engelmannii and P. lumholtzii to recent environmental variability across a 400-m elevation gradient in western Chihuahua. We hypothesized that (1) growth sensitivity to drought of each species would be higher at low elevations than at high elevations, (2) annual BAI would be lower at low elevations than at high elevations, and (3) winter precipitation would covary closely and positively with tree growth at all elevations.

\section{Methods \\ Study Site}

The study was performed in Basaseachi National Park in the Sierra Madre Occidental of western Chihuahua, Mexico. The study area was centered at approximately $108.2^{\circ} \mathrm{W}, 28.2^{\circ} \mathrm{N}$. Elevations ranged from approximately $1750 \mathrm{~m}$ to $2150 \mathrm{~m}$ asl. We believe our study area captured the entire extent of co-occuring $P$. engelmannii and $P$. lumholtzii in the region of Basaseachi National Park. Pinus engelmannii grows predominantly from 2000 to $2500 \mathrm{~m}$ asl, while P. lumholtzii generally grows from 1700 to $2400 \mathrm{~m}$ asl (Perry 1991, Farjon and Styles 1997). Our study area encompassed the lower half of elevation ranges for both species that we studied. According to range maps by Perry (1991) and Farjon and Styles (1997), our study area was located in the northernmost extent of the ranges of both $P$. engelmannii and $P$. lumholtzii. Soils in the study area are classified as Leptosols and Regosols (Cortés unpublished observation) and are of volcanic origin (Spruill 1976).

Weather stations in Mexico are widely spaced and do not have consistent and complete records of climate data. Climate data specific to our study area do not exist. We acquired precipitation and temperature data from 3 weather stations: Guerrero, Chihuahua (elevation $2010 \mathrm{~m}$ asl, $108.517^{\circ} \mathrm{W}, 28.517^{\circ} \mathrm{N}, 47 \mathrm{~km}$ northwest of the study site); Creel, Chihuahua (elevation $2300 \mathrm{~m}$ asl, $107.633^{\circ} \mathrm{W}, 27.75^{\circ} \mathrm{N}, 75 \mathrm{~km}$ southeast of the study site); and Yécora, Sonora (elevation $1500 \mathrm{~m}$ asl, $108.95^{\circ} \mathrm{W}, 28.367^{\circ} \mathrm{N}, 75$ $\mathrm{km}$ west of the study site). These stations were selected because they were closest to and most similar in elevation to the study area and had the most complete weather information from 1945 to 2004 (ERIC II 2002). Annual precipitation at these stations averages approximately $780 \mathrm{~mm}$, of which approximately $50 \%$ falls in July and August. Another 18\% falls from December through April. Dominant tree species include $P$. engelmannii Carrière, Pinus durangensis Martínez, P. lumholtzii Robinson and Fernald, and Pseudotsuga menziesii Schwerin (Spellenberg et al. 1996). Within the study area, we established 3 study sites based on the co-occurrence of $P$. engelmannii and $P$. lumholtzii over an elevation gradient (Fig. 1). We sampled at high and intermediate elevations above Basaseachi Waterfall and at a low elevation below it (Fig. 2).

\section{Tree Core Samples}

We collected increment cores from each of $15 P$. engelmannii and $P$. lumholtzii trees at each of the three sites (Fig. 2). We limited the sample to 15 trees of each species at each elevation to allow the sampling of only healthy trees with similar canopy position. Tree size and age were not strict criteria for tree selection, as there were insufficient individuals of similar canopy position and health to allow strict selection based on diameter at breast height $(\mathrm{dbh})$ and age. We sampled trees ranging in dbh from approximately 20 to $80 \mathrm{~cm}$, although most trees ranged from approximately 30 to 40 


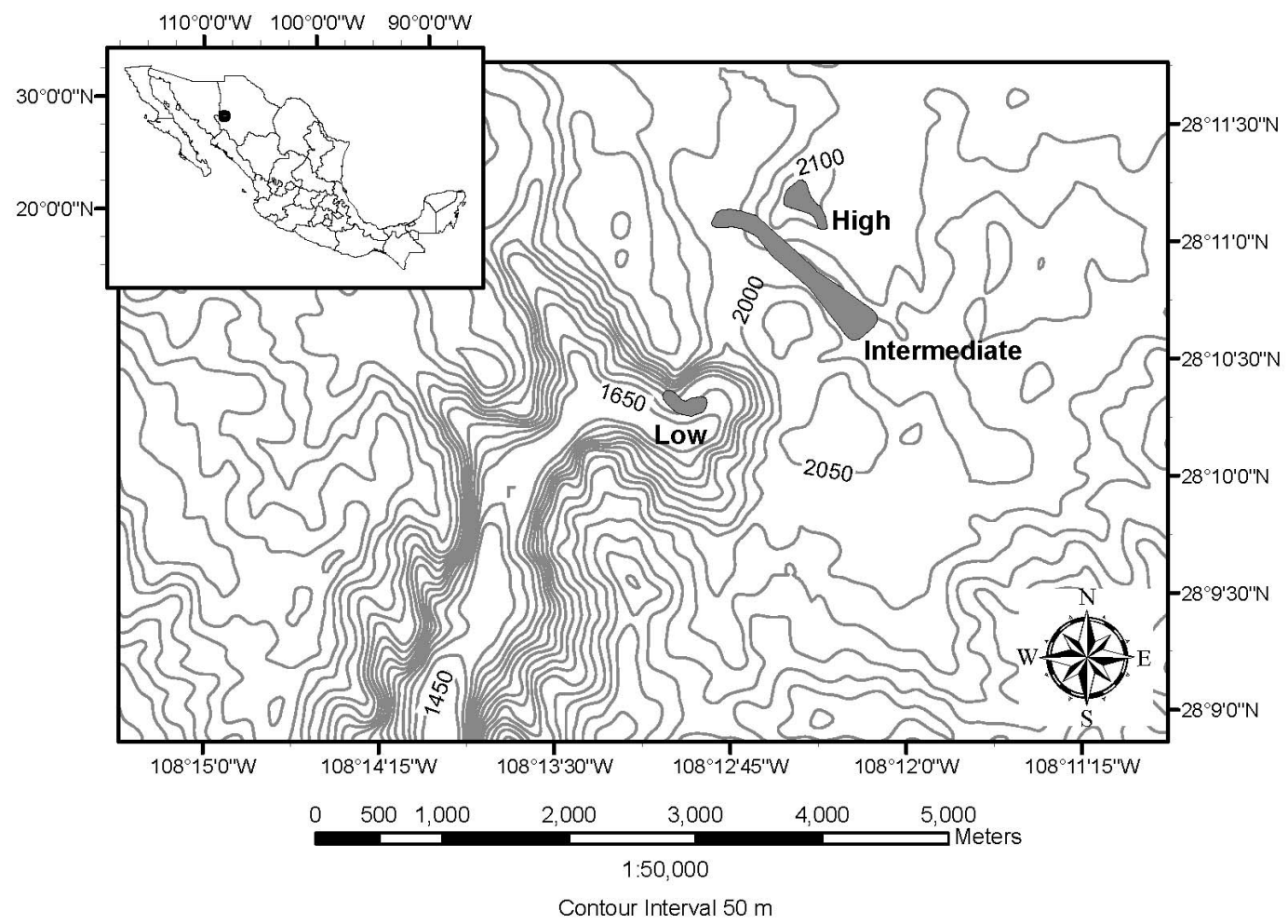

Fig. 1. The study area in Mexico and locations of the low-, intermediate-, and high-elevation sites where trees were sampled.

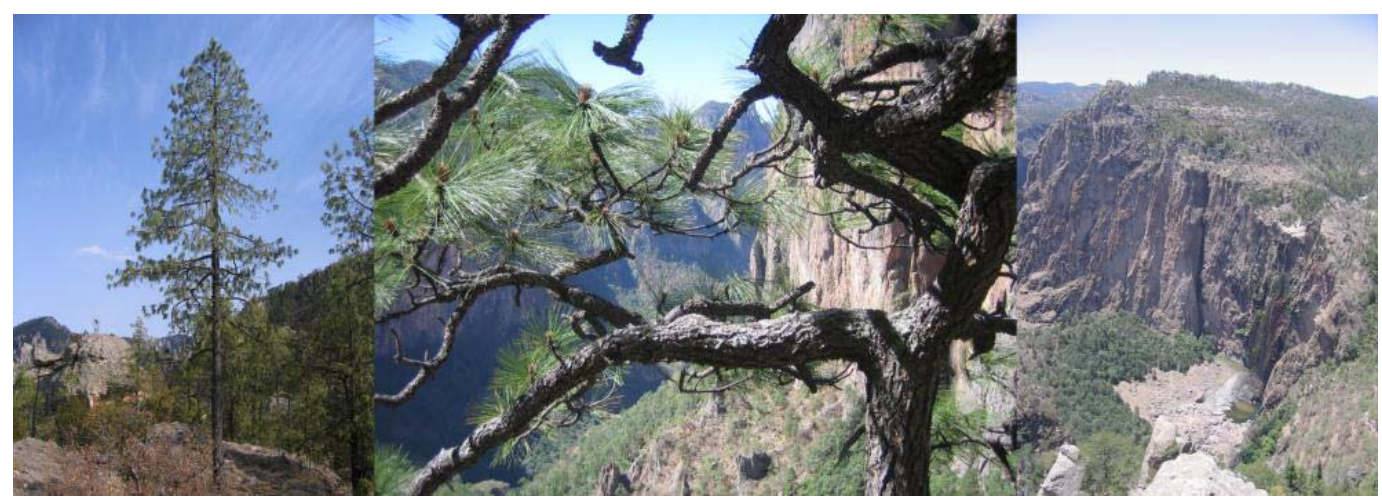

Fig. 2. Tree species and study area: left panel, Pinus lumholtzii; middle panel, Pinus engelmannii; right panel, Basaseachi Falls viewed from the southeast. Part of the low-elevation study site is located in the forested area at the left of this photo.

$\mathrm{cm}$ in dbh. All sampled trees occupied dominant or codominant canopy positions and showed no sign of poor health or insect, lightning, or fire damage. We collected 2 cores from a height of $40 \mathrm{~cm}$ above mineral soil from each tree-one from the uphill side of the tree and one perpendicular to the slope direction—using a 5-mm-diameter increment borer (Haglof, Sweden).

The high-elevation study site differs from the intermediate- and low-elevation sites in slope (Table 1). We were unable to find P. lumholtzii to sample at the high-elevation study site except at the top of a ridge, as $P$. lumholtzii generally 
TABLE 1. Summary of physiographic characteristics for each study site.

\begin{tabular}{lccc}
\hline $\begin{array}{l}\text { Elevation } \\
\text { class }\end{array}$ & $\begin{array}{c}\text { Elevation } \\
(\mathrm{m} \text { asl })\end{array}$ & $\begin{array}{c}\text { Slope } \\
(\%)\end{array}$ & Aspect \\
\hline High & 2129 & 8 & $\mathrm{SE}$ \\
Intermediate & 1998 & 39 & $\mathrm{~W}$ \\
Low & 1741 & 48 & $\mathrm{SE}$ \\
\hline
\end{tabular}

occurs on rocky outcrops at the top of ridges (Farjon and Styles 1997). At the intermediateelevation study site, we were unable to find 15 $P$. engelmannii that fit our selection criteria within a geographical area similar to that of the low- and high-elevation study sites (Fig. 1). As a result, the intermediate-elevation study site had an aspect different from the other study sites (Table 1).

We glued cores to wooden core mounts and sanded them with increasingly fine grits of sandpaper until the annual growth rings were clearly visible under a microscope. We cross-dated cores visually using narrow marker years (Stokes and Smiley 1968) from a pine-composed ring-width chronology for Basaseachi (Irby unpublished data). We then measured ring widths to the nearest $0.01 \mathrm{~mm}$ using an ACU-Rite Measuring Stage (Velmex Inc., NY) and Measure J2X computer software (VoorTech Consulting, Holderness, NH). We checked our visual cross-dating using COFECHA software (Grissino-Mayer 2001; software from International Tree Ring Data Bank Program Library). Cores that did not crossdate were excluded from further analysis.

We recorded age at a height of $40 \mathrm{~cm}$ for each tree. If a core did not include the tree pith, we used a pith locator (Applequist 1958) to estimate age. We averaged the raw ringwidth measurements of the 2 cores from each tree to create a single ring series for each tree. We then standardized the series using ARSTAN software (Cook and Krusic 2005). We used a negative exponential model to remove age- and/or size-related patterns in growth. We then divided the index value in each year by the mean index value for the series to create a residual chronology of ring-width indices (RWI) for each tree and for each of the 6 species-elevation combinations (Fritts and Swetnam 1989). This procedure creates a chronology with a mean value of 1.0 and a minimum value of zero. This model for standardization preserves fine-scale climatic variability and removes other variability from the final chronology. No significant autocorrelation remained in the residual chronology.

\section{Climate Data and Wet-Dry Ratio Analysis}

To focus on recent climate-related growth changes, we limited our wet-dry ratio analysis to a timespan of 60 years from 1945 to 2004 . We created a regional climate data set by averaging precipitation and temperature in each month for the years 1945-2004, using data from the 3 weather stations mentioned above. We designated periods of seasonal climate data based on dominant patterns of precipitation and temperature in the regional climate data set. We defined winter as December through April, premonsoon as May and June, monsoon as July and August, and fall as September through November. We used DendroClim software (Biondi and Waikul 2004) to correlate monthly precipitation with the residual chronologies created for each of the 6 elevation-species combinations in order to identify which months were most highly correlated with tree growth. Winter precipitation was most highly correlated with tree growth.

We summed monthly winter precipitation values from the regional climate data set and selected the 6 wettest and 6 driest years from this time period for analysis (Fig. 3). We divided the average RWI in wet years by the average RWI in dry years for each tree to calculate the wet-dry ratio (W:D). Higher values of this ratio indicate higher growth sensitivity to drought (Fekedulegn et al. 2003, Adams and Kolb 2005). The W:D data were normally distributed and had equal variance. We analyzed the W:D data with a 2-way ANOVA with species, elevation, and their interaction as factors, and used Tukey's HSD tests for mean separations. For all analyses, statistical significance was defined as $P \leq 0.05$.

\section{Basal Area Increment and Climate-Growth Correlation}

We calculated the total radial increment for the years 1998-2007 from the annual ring measurements from tree cores. We estimated $1998 \mathrm{dbh}$ by subtracting the radial increment for the 10-year analysis period from the tree dbh measured in 2008. We then calculated BAI based on the difference between estimated basal area in 1998 and measured basal area in 2008. For these calculations, we assumed the trees grew in circular cross sections and had constant bark thickness from 1998 to 2007 . We also assumed that 2008 earlywood thickness was negligible and that diameter growth at breast height was equal to growth at $40 \mathrm{~cm}$ 


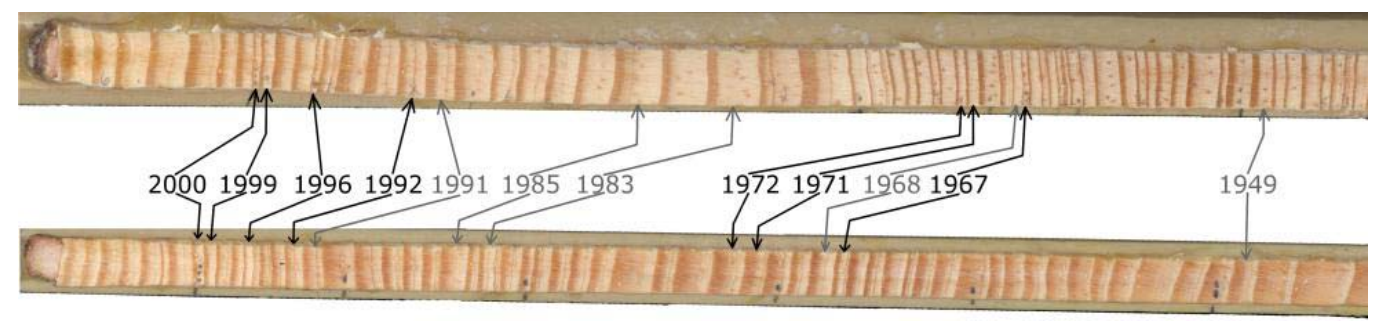

Fig. 3. Cores from high-elevation Pinus engelmannii with wet and dry years labeled. Gray text and arrows represent wet years. Black text and arrows represent dry years. Wet and dry years were determined from climatological data.

TABLE 2. Average, minimum, and maximum tree diameter at breast height ( $\mathrm{dbh}$ ), tree age, and tree height for the 6 elevation/species combinations. PIEN = Pinus engelmannii and PILU = Pinus lumholtzii. Values in parenthesis indicate minimum and maximum values, respectively.

\begin{tabular}{llccc}
\hline Elevation & Species & Average dbh $(\mathrm{cm})$ & Average tree age (years) & Average height $(\mathrm{m})$ \\
\hline High & PIEN & $39.3(32.5,49.3)$ & $104(63,155)$ & $21.0(12.5,31.2)$ \\
High & PILU & $30.5(21,38.4)$ & $113(85,159)$ & $19.3(11.4,26.3)$ \\
Intermediate & PIEN & $33.8(24,44.1)$ & $113(55,209)$ & $20.8(12.6,31.0)$ \\
Intermediate & PILU & $32.9(22.9,48)$ & $136(101,193)$ & $18.8(10.3,32.2)$ \\
Low & PIEN & $57.0(35.1,76.9)$ & $147(93,181)$ & $26.8(19.5,33.8)$ \\
Low & PILU & $33.0(19.9,57.3)$ & $102(72,139)$ & $15.9(11.7,25.2)$ \\
\hline
\end{tabular}

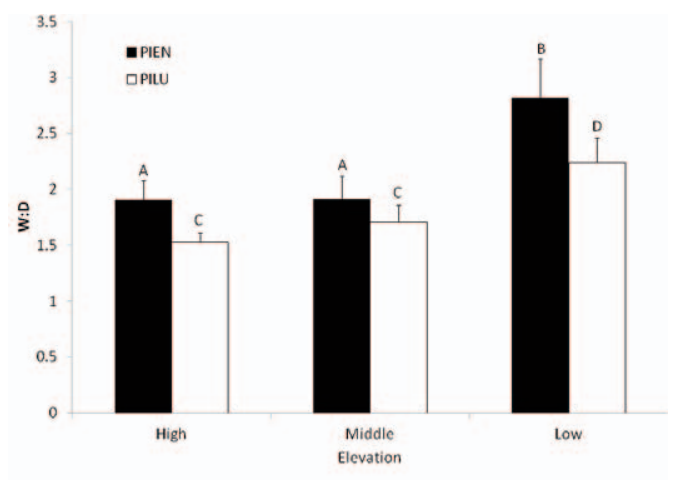

Fig. 4. Wet-dry ratios (W:D) for the 6 elevation-species combinations, with standard error bars. Columns labeled with different letters are statistically different $(\alpha=0.05)$. PIEN = Pinus engelmannii and PILU = Pinus lumholtzii.

above mineral soil. The BAI data were normally distributed and had equal variance. We analyzed the annual BAI data with a 2-way ANOVA with species, elevation, and their interaction as factors.

We calculated linear regression equations to describe relationships between the ring-width chronologies for the 6 elevation-species combinations and precipitation, average temperature, minimum temperature, and maximum temperature for each season (winter, premonsoon, monsoon, and fall) for the years 1945-2004.

\section{Results}

Five of the 6 elevation-species combinations were similar in means and ranges of tree size and age (Table 2). Pinus engelmannii trees at the low-elevation study site had larger average dbh measurements and were slightly older than trees sampled at other sites.

Of the 30 trees sampled at each elevation, 4 high-elevation trees (13\%), 12 intermediate-elevation trees $(40 \%)$, and 14 low-elevation trees (47\%) could not be cross-dated due to frequent missing rings. Of the 60 trees sampled from each species, 18 P. engelmannii (30\%) and 12 P. lumholtzii $(20 \%)$ could not be cross-dated. As a result, the final sample size used for analysis was 13 high-elevation $P$. engelmannii trees, 14 high-elevation $P$. lumholtzii trees, 8 intermediateelevation $P$. engelmannii trees, 10 intermediate-elevation $P$. lumholtzii trees, 7 low-elevation $P$. engelmannii trees, and 9 low-elevation $P$. lumholtzii trees.

Trees at the low-elevation site were significantly more sensitive to drought as indicated by their higher W:D than trees at higher elevations. Average W:D ranged from 1.5 to 2.8 across the 6 elevation-species combinations (Fig. 4). ANOVA showed a significant difference in $\mathrm{W}: \mathrm{D}$ between elevations $(P=0.0002)$ and species $(P=0.0161)$. There was no significant interaction between 
elevation and species. The Tukey's HSD tests separated mean W:D at the low elevation from the high and intermediate elevations for both species, with the low-elevation site having significantly higher W:D than the other 2 elevations. Pinus engelmannii had significantly higher sensitivity to drought $(\mathrm{W}: \mathrm{D}=2.2)$ than $P$. lumholtzii $(\mathrm{W}: \mathrm{D}=1.8)$.

There was no significant difference in average annual BAI from 1998 to 2007 between elevations or species, and there was no significant interaction between elevation and species. Annual BAI averaged over species was $88.6 \mathrm{~cm}^{2}$ $(\mathrm{SE}=10.6)$ at the high elevation, $77.3 \mathrm{~cm}^{2}(\mathrm{SE}=$ $9.6)$ at the intermediate elevation, and $113.9 \mathrm{~cm}^{2}$ $(\mathrm{SE}=18.2)$ at the low elevation. Annual BAI averaged over elevations was $106.7 \mathrm{~cm}^{2}(\mathrm{SE}=$ 12.0) for P. engelmannii and $79.9 \mathrm{~cm}^{2}(\mathrm{SE}=8.7)$ for P. lumholtzii.

Of the seasonal climate variables we tested, winter precipitation was most strongly associated with annual growth $\left(r^{2}\right.$ ranged from 0.14 to $0.44, P$ ranged from 0.0000003 to 0.0044 ). Maximum winter temperature had the second highest association ( $r^{2}$ ranged from 0.13 to $0.25, P$ ranged from 0.0003 to 0.006 ). All other climatic variables we tested were weakly and nonsignificantly associated with annual growth. RWI was positively and significantly associated with winter precipitation for 5 of the 6 elevation-species combinations (Fig. 5). The association was nonsignificant for intermediate-elevation $P$. lumholtzii. Winter precipitation was more strongly associated with tree growth at low elevations than at intermediate and high elevations. RWI was negatively and significantly associated with maximum winter temperature for 4 of the 6 elevation-species combinations (Fig. 6). The association was nonsignificant for high- and intermediate-elevation P. lumholtzii. Maximum winter temperature was more strongly associated with the growth of trees at low elevations than at intermediate or high elevations. Winter precipitation and maximum winter temperature were negatively and significantly associated $(r=$ $\left.-0.46, r^{2}=0.21, P=0.0004\right)$.

\section{DisCUSSION}

Consistent with our first hypothesis, growth sensitivity to drought of $P$. engelmannii and $P$. lumholtzii in Basaseachi National Park was higher at low elevations than at high elevations.
Our results are also consistent with well-established dendrochronological patterns of greater limitations of precipitation to tree growth in low- than in high-elevation forests (Fritts 1974). Higher temperature and lower precipitation typical of lower elevations in northern Mexico generally result in greater plant water stress (Fritts 1974, Van de Water et al. 2002, McDowell et al. 2010), which would increase sensitivity to drought. In all 6 elevation-species combinations, W:D was greater than 1.0, indicating that drought decreased growth for all trees in this study. The high growth sensitivity to drought of these species is consistent with previous reports for other pine species in the southwestern United States, such as Adams and Kolb (2005) and McDowell et al. (2010).

Growth of $P$. engelmannii was more sensitive to drought than growth of $P$. lumholtzii, as indicated by higher W:D. This difference may be partially caused by the greater drought tolerance of $P$. lumholtzii compared with $P$. engelmannii (Perry 1991). Consequently, worsening drought conditions may have a more detrimental effect on growth of $P$. engelmannii than on P. lumholtzii, especially at lower elevations. The insignificant interaction between species and elevation on W:D indicates that this species difference was robust over elevations.

Our second hypothesis, that annual BAI would be lower at low elevations than at higher elevations, was rejected; recent (1998-2007) BAI did not differ between species or elevations. This result differs from McDowell et al.'s (2010) report of lower BAI for low-elevation populations than high-elevation populations of $P$. ponderosa in New Mexico. Our finding of no difference in annual growth between low- and high-elevation populations was likely due to our exclusion of more low- and intermediateelevation trees than high-elevation trees from the growth comparisons due to frequent missing rings that prevented cross-dating. In most cases, these excluded trees had very small rings and a high proportion of missing rings, especially from 1998 to 2008 . We suspect that if these trees could have been cross-dated and included in the BAI analysis, our results may have shown lower annual growth at low elevations than high elevations, similar to McDowell et al. (2010), as more trees were excluded at the low-elevation site than at the high-elevation site. Furthermore, we did not control for site productivity and other soil properties in this study. Perhaps a careful 

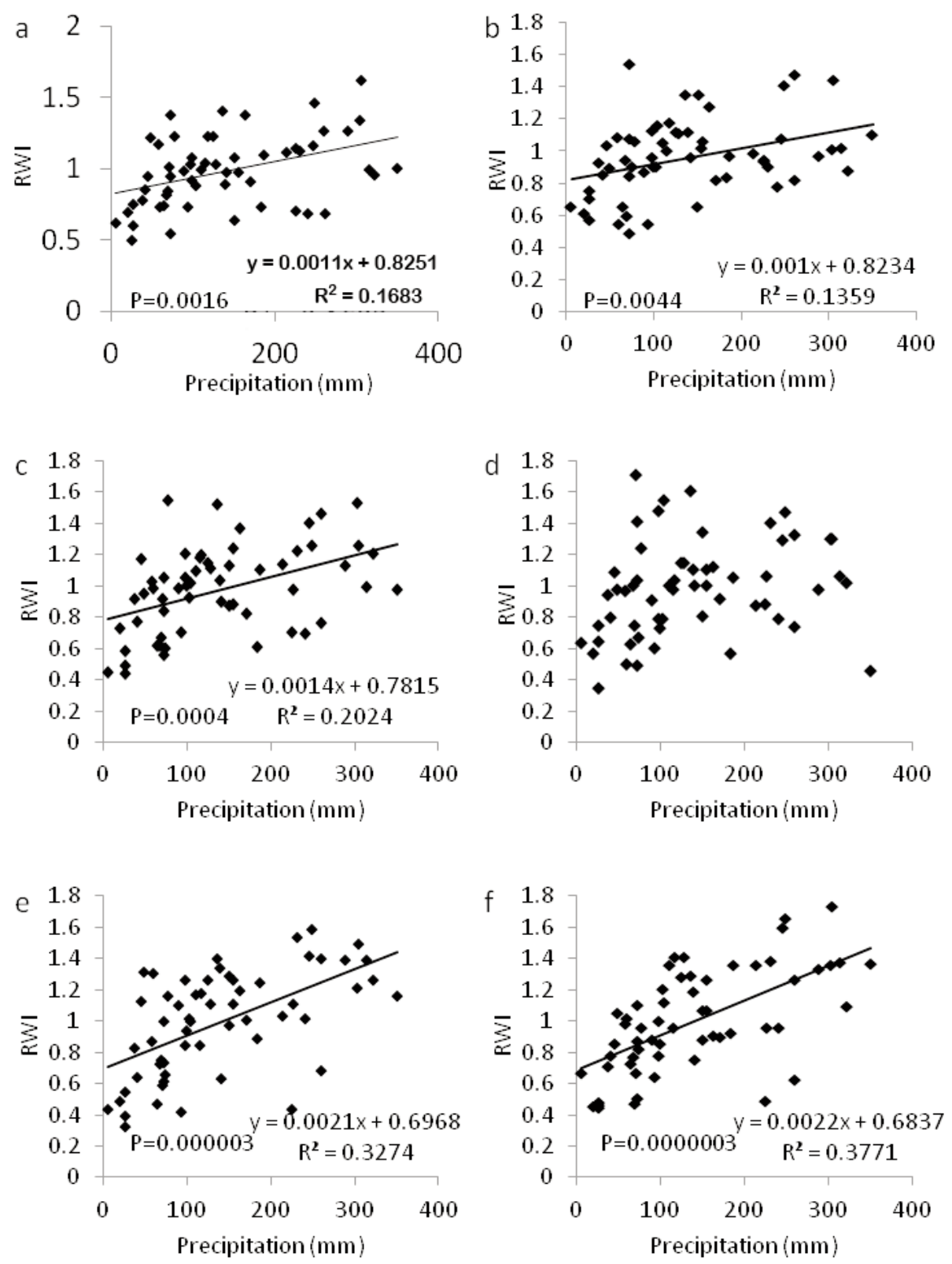

Fig. 5. Functions relating winter precipitation and ring-width index (RWI) for the 6 elevation-species combinations (equations are given only for significant relationships): a, high-elevation Pinus engelmannii; $\mathbf{b}$, high-elevation Pinus lumholtzii; c, intermediate-elevation P. engelmannii; $\mathbf{d}$, intermediate-elevation $P$. lumholtzii; $\mathbf{e}$, low-elevation $P$. engelmannii; $\mathbf{f}$, low-elevation P. lumholtzii.

control of these factors would allow a detectable difference in BAI between elevations.

Winter precipitation covaried positively with tree growth at all elevations and most strongly at low elevations, supporting our third hypothesis. The significant and strongly negative relationship between winter precipitation and maximum winter temperature suggests that warm winters tended to have lower precipitation than cool winters. As a result, the negative relationship between maximum winter temperature and RWI likely occurred because warm winters had less precipitation than cool winters. Based on our findings that winter precipitation was almost 

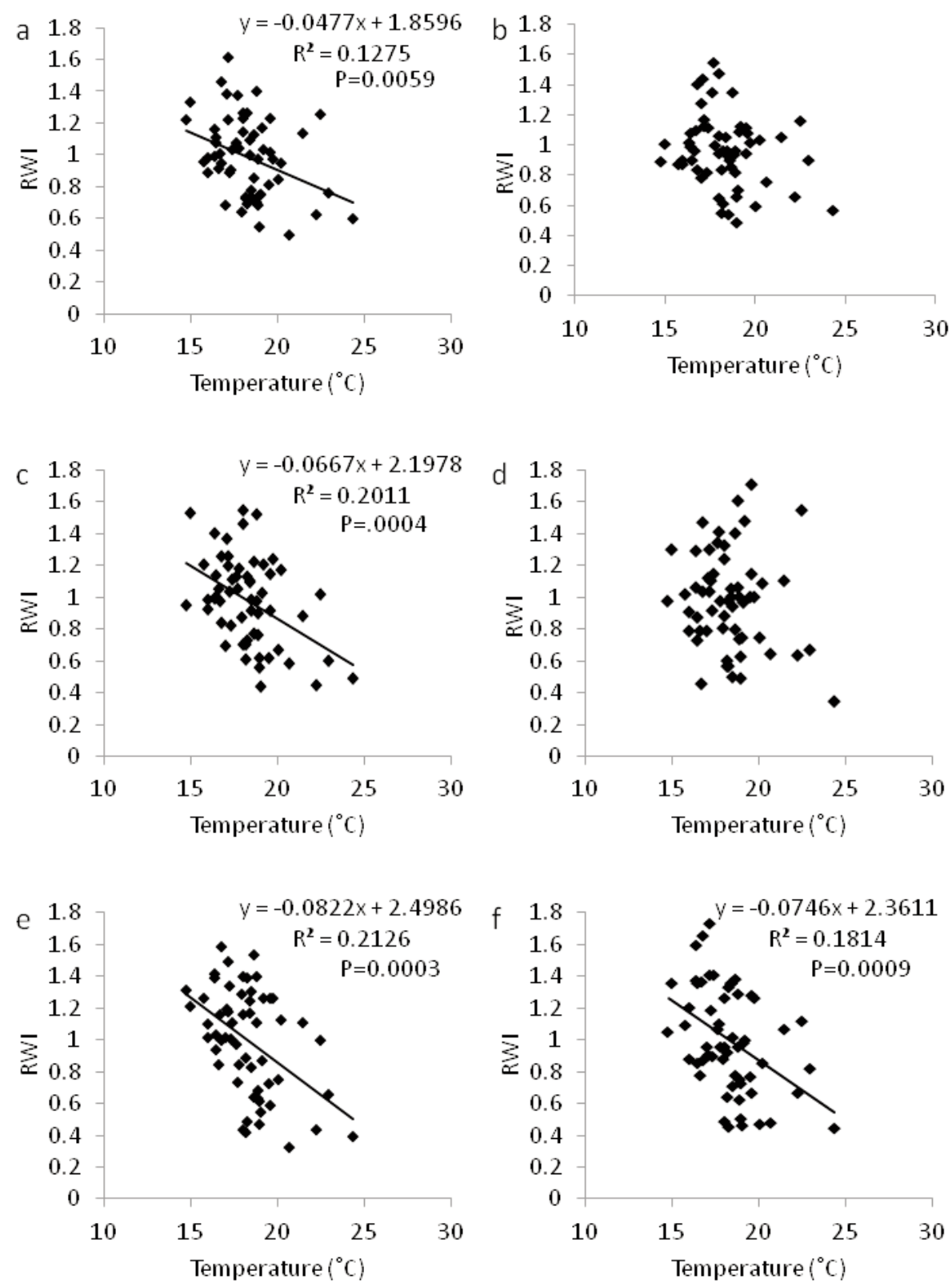

Fig. 6. Functions relating maximum winter temperature and ring-width index (RWI) for the 6 elevation-species combinations (equations are only given for significant relationships): a, high-elevation Pinus engelmannii; $\mathbf{b}$, high-elevation Pinus lumholtzii; $\mathbf{c}$, intermediate-elevation P. engelmannii; $\mathbf{d}$, intermediate-elevation $P$. lumholtzii; $\mathbf{e}$, low-elevation $P$. engelmannii; f, low-elevation P. lumholtzii.

always significantly associated with tree growth (Fig. 5), our results suggest that winter precipitation is the dominant climatic factor that affects tree growth at all elevations within our study area. However, the low $r^{2}$ values for this analysis indicate that the relationships we found offer only a weak basis for prediction. Fritts
(1976) demonstrated that winter precipitation was most strongly correlated with earlywood growth, while summer precipitation was more strongly correlated with latewood growth. An analysis of tree growth that separates earlywood and latewood growth would likely result in stronger relationships between tree growth and 
precipitation than we observed in our study. Although approximately one half of annual precipitation fell in the monsoon season at our study area, it is probable that not all of this moisture was available for tree growth: this moisture was used by other plants, and higher temperatures in the summer caused higher evaporation and transpiration. In contrast, cooler winter temperatures and slow rates of snowmelt allow moisture to penetrate deep soil layers that are important for tree growth because trees are deep-rooted organisms (Fritts 1976).

Growing season temperature was not significantly associated with interannual variation in tree growth at any elevation we studied. Adams and Kolb (2005) found that interannual variation in precipitation tended to be a more limiting factor to tree growth than temperature at elevations below $3300 \mathrm{~m}$ asl in northern Arizona. Our results suggest that trees at the high-elevation site were not above the elevation threshold at which interannual variation in growth is more strongly affected by temperature than by precipitation, although the specific elevation likely differs for our study area compared with that of Adams and Kolb's study area due to differences in latitude. Therefore, trees at all 3 elevations that we studied exhibited greater sensitivity to interannual variation in precipitation than to variation in temperature.

Our finding of greater negative impacts of regional drought on growth of $P$. engelmannii and P. lumholtzii at low elevations than at intermediate and high elevations may portend future impacts of climate warming on these species in the Sierra Madre Occidental of northern Mexico. Based on our results, an increase in drought severity and frequency caused by climate warming will decrease growth of both $P$. engelmannii and P. lumholtzii in Basaseachi National Park, with greater impacts on $P$. engelmannii. This study is the first report of controls on tree growth by climatic variables in this understudied region of Mexico. A drought-induced reduction in growth may indicate a reduction in carbon allocation to sinks other than radial growth, such as resin defenses against lethal bark beetle attacks (Waring and Schlesinger 1985, McDowell et al. 2007, 2008). The increase in growth sensitivity to drought of these species, with future climate warming inferred from the response of low-elevation populations, suggests a future surge of tree mortality similar to reports for other pines in the southwestern United States
(Ogle et al. 2000, Breshears et al. 2005, McDowell et al. 2010). Therefore, this study should be considered by forest management and conservation agencies in Mexico, as it provides information on the potential impacts of climate warming on conifers of the Sierra Madre Occidental.

\section{ACKNOWLEDGMENTS}

This research was funded by the Ecological Restoration Institute, a Northern Arizona University Hooper Grant for Undergraduate Research, and a Research Experience for Undergraduates Grant from the National Science Foundation. We thank the Ejido Basaseachi and Basaseachi National Park for permission to perform this study. We also thank Larissa Yocom, Christen Irby, Don Normandin, Walker Chancellor, Robin Long, Daniel Laughlin, Citlali Cortés Montaño, Rachael Biggs, Kirstie Bickford, Michael Garcia, and Ty Nietupski.

\section{Literature Cited}

ADAMs, H.D., AND T.E. KoLB. 2005. Tree growth response to drought and temperature along an elevation gradient on a mountain landscape. Journal of Biogeography 32 : 1629-1640.

Applequist, M.B. 1958. A sample pith locator for use with off-center increment cores. Journal of Forestry $56: 141$.

Asbjornsen, H., K.A. Vogt, And M.S. Ashton. 2004. Synergistic responses of oak, pine, and shrub seedlings to edge environments and drought in a fragmented tropical highland oak forest, Oaxaca, Mexico. Forest Ecology and Management 192:313-334.

BIONDI, F. 2001. A 400-year tree-ring chronology from the tropical treeline of North America. Ambio 30(3): 162-166. Available from: http://wolfweb.unr.edu/ homepage/fbiondi/Biondi2001lowres.pdf

BIONDI, F., AND K. WAIKUL. 2004. DENDROCLIM2002: a $\mathrm{C}++$ program for statistical calibration of climate signals in tree-ring chronologies. Computational Geosciences 30:303-311. Available from: https://www2 .nancy.inra.fr/unites/lerfob/ecologie-forestiere/pagesperso/f-lebourgeois/documents/docrecherche/ Biondi_Waikul_2004_CompGoes.pdf

Breshears, D.D., N.S. CoBb, P.M. Rich, K.P. Price, C.D. Allen, R.G. Balice, W.H. Romme, J.H. Kastens, M.L. Floyd, J. Belnap, et AL. 2005. Regional vegetation die-off in response to global-change-type drought. Proceedings of the National Academy of Sciences 102(42):15144-15148.

Breshears, D.D., T.E. Huxman, H.D. Adams, C.B. Zou, AND J.E. Davison. 2008. Vegetation synchronously leans upslope as climate warms. Proceedings of the National Academy of Sciences 105(33):11501-11502.

CoOk, E.R., AND P.J. Krusic. 2005. Program ARSTAN [software]. Available from Tree-Ring Laboratory, Lamont Doherty Earth Observatory of Columbia 
University. Available from: http://www.ldeo.columbia .edu/res/fac/trl/public/publicSoftware.html

Diaz, S.C., R. Touchan, and T.W. Swetnam. 2001. A tree-ring reconstruction of past precipitation for Baja California Sur, Mexico. International Journal of Climatology 21:1007-1019. Available from: http://www.ltrr arizona.edu/ tswetnam/tws-pdf/DiazEtal.pdf

[ERIC II] EXTractor RÁPIdo de INFORMación CLIMATOLOGÍA. 2002. Instituto Mexicano de Tecnología del Agua. Available from: http://www.imta.gob.mx/english/ productos/software/meteorologia.html

Farjon, A., and B.T. Styles. 1997. Flora Neotropica Monograph 75: Pinus (Pinaceae). New York Botanical Garden, New York, NY.

Fekedulegn, D., R.R. Hicks, and J.J. Colbert. 2003. Influence of topographic aspect, precipitation and drought on radial growth of four major tree species in an Appalachian watershed. Forest Ecology and Management 177:409-425. Available from: http://www.ncrs .fs.fed.us/pubs/jrnl/2003/ne_2003_fekedulegn_001.pdf

Figueroa-Rangel, B.L., K.J. Willis, and M. OllveraVARGAS. 2008. 4200 years of pine-dominated upland forest dynamics in west-central Mexico: human or natural legacy? Ecology 89:1893-1907.

FriTTS, H.C. 1965. Tree-ring evidence for climatic changes in western North America. Monthly Weather Review 93:421-443. Available from: http://docs.lib.noaa.gov/ rescue/mwr/093/mwr-093-07-0421.pdf

1974. Relationships of ring widths in arid-site conifers to variations in monthly temperature and precipitation. Ecological Monographs 44:411-440.

1976. Tree rings and climate. Academic Press, London, England.

Fritts, H.C., D.G. Smith, And M.A. StoKes. 1965. The biological model for paleoclimatic interpretation of Mesa Verde tree-ring series. Memoirs of the Society for American Archaeology 19:101-121. Available from: http://www.jstor.org/stable/pdfplus/25146673.pdf

FritTs, H.C., AND T.W. Swetnam. 1989. Dendroecology: a tool for evaluating variations in past and present forest environments. Advances in Ecological Research 19:111-188.

Grissino-Mayer, H.D. 2001. Evaluating crossdating accuracy: a manual and tutorial for the compute program COFECHA. Tree Ring Research 57:205-220. Available from: http://www.treeringsociety.org/TRB TRR/TRRvol57_2 205-221.pdf

Kelly, A.E., AND M.L. Goulden. 2008. Rapid shifts in plant distribution with recent climate change. Proceedings of the National Academy of Sciences 105: 11823-11826.

McDowell, N., W.T. Pockman, C.D. Allen, D.D. Breshears, N. Сobb, T. Kolb, J. Plaut, J. Sperry, A. West, D.G. Williams, and E.A. YePEZ. 2008. Mechanisms of plant survival and mortality during drought: why do some plants survive while others succumb to drought? New Phytologist 178:719-739.

McDowell, N.G., H.D. ADams, J.D. Bailey, and T.E. KoLB. 2007. The role of stand density on growth efficiency, leaf area index, and resin flow in southwestern ponderosa pine forests. Canadian Journal of Forest Research 37:343-355. Available from: http://www.lanl .gov/source/orgs/ees/ees14/pdfs/07McDowellCanJ.pdf

McDowell, N.G., C.D. Allen, and L. Marshall. 2010. Growth, carbon-isotope discrimination, and drought- associated mortality across a Pinus ponderosa elevational transect. Global Change Biology 16:399-415.

Ogle, K., T.G. Whitham, and N.S. Совb. 2000. Tree-ring variation in pinyon predicts likelihood of death following severe drought. Ecology 81:3237-3243.

PerRy, J.P. 1991. The pines of Mexico and Central America. Timber Press, Portland, OR.

Ruelas Monjardin, L.C., and R. Dávalos Soteno. 1999. La industria forestal en el estado de Chihuahua. Madera y Bosques 5(2):19-91. Available from: http:// redalyc.uaemex.mx/src/inicio/ArtPdfRed.jsp?iCve= 61750207

Salzer, M.W., And K.F. Kipfmueller. 2005. Reconstructed temperature and precipitation on a millennial timescale from tree-rings in the southern Colorado Plateau, USA. Climatic Change 70:465-487.

Seager, R., M. Ting, M. Davis, M. Cane, N. Naik, J. Nakamura, C. Li, E. Cook, and D.W. Stahle. 2009. Mexican drought: an observational modeling and tree ring study of variability and climate change. Atmósfera 22(1):1-31. Available from: http://www .ejournal.unam.mx/atm/Vol22-1/ATM002200101.pdf

Seager, R., M.F. Ting, I.M. Held, J.L. Kushnir, G. VecCHI, H.P. Huang, N. Harnik, A. Leetmaa, N.C. Lau, C. LI, ET AL. 2007. Model projections of an imminent transition to a more arid climate in southwestern North America. Science 316:1181-1184.

[SEMARNAT] SECRETARÍA de Medio Ambiente y Recursos Naturales. 2002. Inventario nacional forestal 2000. Versión preliminar.

Spellenberg, R., T. Lebgue, and R. Corral-Díaz. 1996. A specimen based, annotated checklist of the vascular plants of Parque Nacional "Cascada de Basaseachi" and adjacent areas, Chihuahua, Mexico. México Instituto de Biología, UNAM.

Spruill, R.K. 1976. The volcanic geology of the Rancho Peñas Azules area, Chihuahua, Mexico. Doctoral dissertation, East Carolina University, Greenville, NC.

Stahle, D.W., E.R. Cook, J. Villanueva-Díaz, F.K. Fye, D.J. Burnette, R.D. Griffin, R. Acuña-Soto, R. SEAGER, AND R.R. HEIM JR. 2009. Early 21st-century drought in Mexico. Eos 90(11):89-100. Available from: http://stage-usmex.ucsd.edu/assets/022/10146.pdf Stokes, M.A., AND T.L. SMILEY. 1968. An introduction to tree-ring dating. University of Chicago Press, Chicago, IL

Swetnam, T.W., and J.L. Betancourt. 1998. Mesoscale disturbance and ecological response to decadal climatic variability in the American Southwest. Journal of Climate 11:3128-3147.

VAN DE Water, P.K., S.W. LEaVitT, and J.L. Betancourt. 2002. Leaf $\delta 13 \mathrm{C}$ variability with elevation, slope aspect, and precipitation in the southwest United States. Oecologia 132(3):332-343.

Villanueva-Diaz, J., D.W. Stahle, B.H. Luckman, J. Cerano-Paredes, M.D. Therrel, M.K. Cleaveland, AND E. CoRnejo-Oviedo. 2007. Winter-spring precipitation reconstructions from tree rings for northeast Mexico. Climatic Change 83:117-131.

WARING, R.H., AND W.H. SCHLESINGER. 1985. Forest ecosystems: concepts and management. Academic Press, San Diego, CA.

Received 21 October 2010 Accepted 5 April 2011 